DOI: 10.32844/2222-5374-2020-104-2.50

УДК: 343.13

Смирнов В. А.,

здобувач Харківського національного університету внутрішніх справ, голова Печенізького районного суду Харківської області

\title{
ПРАВОВІ НАСЛІДКИ ВИЗНАННЯ ДОКАЗІВ НЕДОПУСТИМИМИ: ПОСТАНОВКА ПРОБЛЕМИ
}

Метою статті є визначення поняття «правові наслідки визнання доказів недопустимими», формулювання їх системи та особливостей застосування. В статті розглянуто проблемні аспекти визначення недопустимості доказів. Доведено, що визнання доказів недопустимими $\epsilon$ юридичним фактом та наведено аргументи на підтвердження цього. Встановлено, що поняття правових наслідків визнання доказів недопустимими $\epsilon$ не зовсім висвітленим в юридичній доктрині, а вченими-процесуалістами висловлюються різні бачення щодо категорії досліджуваного поняття. Законодавець у положеннях КПК України також прямо не визначає правові наслідки визнання доказів недопустимими. Автором підтримано наукову позицію, що в будь-якому випадку виключення недопустимого доказувстановлює певні правові наслідки для доказовоїбази, суб'єктів кримінального процесу, визначає напрямки і межі обвинувачення, кримінального переслідування, застосування заходів процесуального примусу, впливає на процесуальний статус підозрюваного, обвинуваченого, а також на постановлення вироку та прийняття рішень в апеляційному та касаційному порядках. На підставі вивчення доктринальних та законодавчих положень визначено, що систему правових наслідків визнання доказів недопустимими складають основні та додаткові наслідки. До основних належать: 1) втрата ним юридичної сили, неможливість його врахування при прийнятті процесуальних рішень і при доведенні обставин, які входять до предмету доказування; 2) преюдиційність рішення суду щодо визнання недопустимим доказу; 3) виключення посилання на такий доказ у мотивувальній частині вироку суду першої інстанції; 4) необхідність вжиття заходів з перевірки законності дій сторони обвинувачення під час досудового розслідування. Додатковими наслідками є винесення судом виправдувального вироку, скасування або зміна судом апеляційної інстанції вироку на підставі невідповідності висновків суду, викладених у судовому рішенні, фактичним обставинам кримінального провадження, а також закриття провадження.

Ключові слова: доказ, допустимість, недопустимість доказів, юридичний факт, правові наслідки.

Актуальність теми. Допустимість доказів у кримінальному процесі $€$ одним із ключових понять, адже має велике значення як у теоретичному, так і в практичному аспекті. Пояснюється це тим, що, з однієї сторони, 
допустимість, будучи однією із властивостей доказів, у значній мірі впливає на повноту досудового розслідування, встановлення усіх обставин, що мають значення для кримінального провадження. 3 іншого боку, допустимість має вельми важливе значення для на забезпечення прав, свобод та законних інтересів учасників кримінального провадження, зокрема, для постановлення вмотивованого, обгрунтованого і законного судового рішення. Вказане наочно підтверджується висновком Верховного Суду України, яким ще у 2001 році акцентував увагу на тому, що перевірка доказів на їх допустимість $€$ гарантією забезпечення прав і свобод людини і громадянина в кримінальному процесі та ухвалення законного і справедливого рішення у справі [1]. Даний аспект не втратив своєї важливості і в умовах правозастосування чинного КПК України.

Аналіз останніх досліджень і публікацій. Питання допустимості доказів у кримінальному процесі завжди викликали великий науковий інтерес та досліджувалися такими вченими-процесуалістами, як Н.М. Басай, В.В. Вапнярчук, Ю.М. Грошевий, Я.П. Зейкан, І.Ю. Кайло, О.В. Капліна, Л.М. Лобойко, В.Т. Нор, О.С. Осетрова, А.В. Панова, В.М. Савицький, С.М. Стахівський, В.В. Тютюнник, О.Г. Шило, М.Є. Шумило тощо. Натомість, окремі аспекти процедури та підстав визнання доказів недопустимими, утому числі й її правові наслідки ,залишаються дослідженими не в повній мірі та викликають багато наукових дискусій.

Метою наукової статті $\boldsymbol{\epsilon}$ визначення поняття «правові наслідки визнання доказів недопустимими», формулювання їх системи та особливостей застосування.

Виклад основного матеріалу. Вивчаючи проблематику правових наслідків визнання доказів недопустимими, насамперед, звернемо увагу на той факт, що поняття «правові наслідки» широко використовується в юриспруденції, однак, на законодавчому рівні не міститься визначення зазначеного терміну.

У загальному розумінні термін «наслідок» означає те, що виходить, випливає з чого-небудь; результат [2, с. 192]. Своєю чергою, правовий наслідок, на нашу думку, доцільно визначати як результати настання певного юридичного факту, які встановлені чинним законодавством. Отже, постає необхідність у з'ясуванні питання, чи є визнання доказів недопустимими юридичним фактом. Для вирішення цього питання звернемося до теорії права, де під юридичним фактом розумуються конкретні обставини соціальної ситуації як підстава виникнення правових наслідків. 3 іншого боку, воно також тлумачиться як правова модель (у формі вироку, рішення суду, різних правових актів тощо). Утворюючи таку модель, потрібно враховувати, що юридичний факт містить ознаки не лише зазначеної конкретної соціальної ситуації, а й ознаки, які не входять до структури даного явища. Модель юридичного факту закріплюється в нормі права (або декількох нормах). Між гіпотезою норми права і моделлю факту не слід ставити знаку рівності, адже вони не співпадають за обсягом - модель фактичного складу може бути закріплена в гіпотезах декількох норм права [3, с. 207]. Інше визначення юридичного факту полягає в тому, що це конкретні соціальні обставини, які мають значення для суб'єкта права у зв'язку з реалізацією його потреб та інтересу, властивості яких описано 
в нормі права як знання про умови, що викликають юридичні наслідки [3, C. 208].

Щодо визначення юридичних фактів у кримінальному провадженні, слід навести думку I. I. Сливича, який розглядає його якпередбачені нормами кримінально-процесуального права конкретні соціальні обставини, що встановлюються в межах певної кримінально-процесуальної форми, 3 якими пов>язується виникнення встановлених вказаними нормами правових наслідків, у тому числі виникнення, зміни, призупинення, припинення або відновлення процесуальних правовідносин, набуття учасниками кримінально-процесуальної діяльності процесуальної правосуб〉єктності [4, с. 14]. Однак, у своєму дисертаційному дослідженні науковець не розглядав питання визнання доказів недопустимими як юридичного факту. Натомість, виходячи із запропонованого ним визначення, можна стверджувати, що визнання доказів недопустимими також $\epsilon$ юридичним фактом, оскільки: 1) зазначена процедура закріплюється нормами кримінального процесуального права; 2) вона має значення для учасників кримінального провадження у зв'язку з реалізацією їх процесуальних прав і обов'язків; 3) встановлюється в межах кримінальної процесуальної форми; 4) виражається у формі судового рішення (ухвала або вирок суду); 5) визнання доказів недопустимими тягне за собою настання певних правових наслідків.

Отже, визнання доказів недопустимими, у розумінні юридичного факту, можна визначити як встановлену в межах кримінальної процесуальної форми процедура, яка виражена у формі судового рішення (ухвала, вирок, постанова) та тягне за собою настання певних юридичних наслідків.

Поняття правових наслідків визнання доказів недопустимими $\epsilon$ не зовсім висвітленим у правовій доктрині. Вченими-процесуалістами висловлюються різні бачення стосовно досліджуваної дефініції. Наприклад, I.Ю. Кайло розглядає юридичні наслідки визнання доказів недопустимими як одну зі складових структури інституту допустимості доказів, а саме поряд із такими його групами, як: поняття доказів і форм закріплення доказової інформації; критерії допустимості доказів і процедуру оцінки доказового матеріалу на предмет допустимості; правила проведення слідчих дій і фіксації доказової інформації; вимоги до суб>єктів, які здійснюють збирання доказового матеріалу й питання відводів [5, с. 27].

КПК України прямо не визначає правові наслідки визнання доказів недопустимими, а дослідження положень цього Кодексу вказує на те, що поняття «правові наслідки» вживається в лише тричі, а саме: щодо подання скарги на рішення, дії чи бездіяльність слідчого, дізнавача чи прокурора під час досудового розслідування (ст. 305 КПК України); розгляду справи судом присяжних (ст. 384 КПК України); організації виконання покарання щодо переданої засудженої особи (ст. 611 КПК України). Хоча, на нашу думку, вживання у кримінальному процесуальному законі терміну «наслідок» передбачає в більшості саме правові наслідки настання того чи іншого юридичного факту.

Відтак, вважаємо, що правові наслідки визнання доказів недопустимими доцільно визначити як результат настання юридичного факту - 
визнання судом недопустимості доказу, який передбачає втрату ним юридичної сили та неможливість його подальшого використання у кримінальному провадженні.

Питання визначення конкретних правових наслідків визнання доказів недопустимими не $€$ прямо врегульованим кримінальним процесуальним законодавством України. Частина 2 ст. 86 КПК України містить вказівку на те, що недопустимий доказ не може бути використаний при прийнятті процесуальних рішень, на нього не може посилатися суд при ухваленні судового рішення. Також вважаємо, що можна розглядати як правовий наслідок в питанні допустимості доказів преюдиціальне значення судових рішень. Зазначене положення передбачене ст. 90 КПК України, відповідно до якої рішення національного суду або міжнародної судової установи, яке набрало законної сили і ним встановлено порушення прав людини і основоположних свобод, гарантованих Конституцією України і міжнародними договорами, згода на обов'язковість яких надана Верховною Радою України, має преюдиціальне значення для суду, який вирішує питання про допустимість доказів [6].

Слід погодитися 3 науковою позицією, згідно з якою у будьякому випадку виключення недопустимого доказу також встановлює певні правові наслідки для доказової бази, суб'єктів кримінального процесу, визначає напрямки та межі обвинувачення, кримінального переслідування, застосування заходів процесуального примусу, впливає на процесуальний статус підозрюваного, обвинуваченого та, в цілому, на рух кримінального провадження, а також на постановлення вироку та прийняття рішень в апеляційному та касаційному порядках [7]. I як на наш погляд слушно зазначає Н.М. Басай, коло правових наслідків визнання доказів недопустимими залежить від істотності значення цього доказу для кримінального процесу і повноважень суб'єкта оцінки у відповідній стадії кримінального провадження, в якій доказ визнаний недопустимим [8, c. 7]. 3 такого тези випливає, що автор вважає поняття «правові наслідки недопустимості доказів» оціночним.

Крім того, Н. М. Басай запропонувала поділяти правові наслідки визнання доказів недопустимими 3 їх конкретизацією щодо кожної зі стадій кримінального процесу. На їі думку, залежно від істотності значення для кримінального провадження визнаного недопустимим доказу правові наслідки доцільно класифікувати на дві групи: 1) основні, які впливають на кінцеве рішення конкретної стадії кримінального провадження; 2) додаткові, які зумовлені основними наслідками [8, с. 6]. Вважаємо слушною таку наукову позицію. Також цілком погоджуємося з тим, що основним обов'язковим наслідком визнання доказу недопустимим як під час досудового розслідування, так і в судових стадіях кримінального провадження виступають втрата ним юридичної сили, неможливість його врахування при прийнятті процесуальних рішень і при доведенні обставин, які входять до предмету доказування. Інші основні правові наслідки залежать від істотності значення для кримінального провадження доказу, який визнаний недопустимим, і наданих суб'єкту оцінки повноважень. Зокрема, до основних наслідків вчена відносить: 1) постановлення виправдувального вироку; 2) виключення посилання на доказ, визнаний недопустимим, у мо- 
тивувальній частині вироку суду першої інстанції; 3) скасування вироку суду чи постанови першої інстанції та повернення справи на новий судовий розгляд у суд першої інстанції; 4) скасування вироку суду першої інстанції та закриття справи у зв'язку з недоведеністю участі підсудного у вчиненні інкримінованого злочину тощо [8, с. 15-16].

Стосовно постановлення виправдувальних вироків зазначимо, що відповідно до судової статистики їх відсоток вкрай низький - не більше 2\%. Так, із загальної кількості засуджених судами I інстанції у 2019 році (70375), кількість виправданих осіб становить 987, що складає 1,4\%. Після перегляду цих вироків в апеляційному та касаційному порядку, зазначена цифра становить 171. В апеляційному порядку виправдувальні вироки скасовано стосовно 311 осіб, із них у зв'язку зі скасуванням необгрунтованого виправдувального вироку апеляційні суди постановили нові вироки стосовно 49 осіб. У касаційному порядку перевірено виправдувальні вироки стосовно 215 осіб, із них скасовано вироки із призначенням нового розгляду стосовно 89 осіб [9]. Тож, беручи до уваги приведену статистику, можна констатувати, що цей правовий наслідок настає у випадку визнання доказів недопустимими вкрай рідко. До того ж, останньою судовою інстанцією, яка уповноважена вирішувати питання допустимості (недопустимості) доказів, $є$ касаційний суд, який також має межі перегляду судових рішень. Як зазначила суддя Касаційного кримінального суду Верховного суду С. Яковлєва, у касаційних скаргах, які надходять до суду, досить часто ставиться питання про необхідність дослідження касаційним судом доказів у зв'язку з їх неправильною оцінкою та про визнання цих доказів недопустимими або неналежними. Однак межі перегляду судом касаційної інстанції судових рішень чітко визначені нормами КПК України. Суд касаційної інстанції не має права досліджувати докази та надавати їм оцінку, він перевіряє правильність застосування судами першої та апеляційної інстанцій норм матеріального та процесуального права, правової оцінки обставин [10].

Ще одним наслідком визнання доказів недопустимими $є$ виключення посилання на такий доказ у мотивувальній частині вироку суду першої інстанції. Згідно вимог п. 2 ч. 3 ст. 374 КПК України, мотивувальна частина вироку повинна містити докази на підтвердження встановлених судом обставин, а також мотиви неврахування окремих доказів. Вважаємо, що за змістом цієї норми в мотивувальній частині як обвинувального, так і виправдувального вироку мають бути викладені результати дослідження, аналізу та оцінки доказів у справі, як тих, що були зібрані як стороною обвинувачення, так і стороною захисту.

Щодо скасування вироку суду першої інстанції та повернення справи на новий судовий розгляд у суд першої інстанції як правового наслідку визнання доказів недопустимими, чинний КПК України не містить такого наслідку визнання недопустимості доказів Відповідно до ст. 415 КПК України, суд апеляційної інстанції скасовує вирок чи ухвалу суду і призначає новий розгляд у суді першої інстанції, якщо: 1) встановлено порушення, передбачені пунктами 2, 3, 4, 5, 6, 7 ч. 2 ст. 412 КПК України (процедурні порушення вимог кримінального процесуального закону під час розгляду кримінальної справи в суді; 2) в ухваленні судового рішення брав участь 
суддя, якому було заявлено відвід на підставі обставин, які очевидно викликали сумнів у неупередженості судді, і заяву про його відвід визнано судом апеляційної інстанції обгрунтованою; 3) судове рішення ухвалено чи підписано не тим складом суду, який здійснював судовий розгляд [6].

Правовими наслідками визнання недопустимості доказів судом апеляційної інстанції $\epsilon$ скасування або зміна судом апеляційної інстанції вироку на підставі невідповідності висновків суду, викладених у судовому рішенні, фактичним обставинам кримінального провадження (ст. 409 КПК України), а також закриття провадження.

Додаткові правові наслідки визнання доказів недопустимими обумовлюються основними наслідками і можуть полягати у: 1) зміні складеного слідчим списку осіб, які підлягають виклику у судове засідання; 2) скасуванні або зміні обраного раніше запобіжного заходу; 3) зміні прокурором обвинувачення; 4) скасуванні арешту майна; 5) вирішенні питання про речові докази, зокрема про гроші, цінності та інші речі, нажиті злочинним шляхом; 6) виникненні у виправданого права на поновлення його порушених прав і відшкодування шкоди, завданої внаслідок незаконного затримання, застосування запобіжного заходу, засудження [8, с. 15-16]. Вважаємо, що зазначені наслідки також не $\epsilon$ обов'язковими, і в кожному конкретному випадку застосовуються в залежності від ситуації, яка склалася в кримінальному провадженні. Але, враховуючи судову практику, приходимо до міркування, що додаткові правові наслідки із запропонованої класифікації наступають вкрай рідко. Така ситуація зумовлена тим, що, незважаючи на положення ст. 87 КПК України щодо можливості визнання недопустимими доказів, отриманих $з$ істотними порушеннями прав людини під час будь-якого судового розгляду, крім розгляду, якщо вирішується питання про відповідальність за вчинення зазначеного істотного порушення прав та свобод людини, внаслідок якого такі відомості були отримані, суд вирішує питання допустимості (недопустимості) доказів під час прийняття остаточного рішення у справі $[11 ; 12 ; 13 ; 14]$.

Якщо розглянути питання настання правових наслідків з точки зору їх впливу на учасників кримінального провадження, доцільно зазначити, що вони обов'язково повинні його мати, оскільки непоодинокими $\epsilon$ випадки неналежного порядку проведення слідчих (розшукових), негласних слідчих (розшукових), інших процесуальних дій та навіть неналежного виконання представниками сторони обвинувачення своїх посадових обов'язків. Адже більш сумлінне ставлення до проведення якісного досудового розслідування дозволить попередити процесуальні порушення та забезпечити більш якісний збір доказів та їх допустимість.

Висновки. Резюмуючи проведене дослідження, вважаємо, що систему правових наслідків визнання доказів недопустимими складають основні та додаткові наслідки. На нашу думку, до основних належать: 1) втрата доказом юридичної сили, а отже й неможливість його врахування при прийнятті процесуальних рішень і при доведенні обставин, які входять до предмету доказування; 2) преюдиційність рішення суду щодо визнання недопустимим доказу; 3) виключення посилання на такий доказ у мотивувальній частині вироку суду першої інстанції; 4) необхідність 
вжиття заходів з перевірки законності дій сторони обвинувачення під час досудового розслідування. Додатковими наслідками $є$ винесення судом виправдувального вироку, скасування або зміна судом апеляційної інстанції вироку на підставі невідповідності висновків суду, викладених у судовому рішенні, фактичним обставинам кримінального провадження, а також закриття провадження.

\section{СПИСОК ВИКОРИСТАНИХ ДЖЕРЕЛ}

1. Рішення Конституційного суду України від 20.102001 № 12рп/2011. URL: https://zakon.rada.gov.ua/laws/show/v012p710-11.

2. Словник української мови в 11 томах : за заг. ред. І. Білодіда . Т.5: уклад. А.А. Бурячок, В.М. Білоноженко, А.П. Білоштан та ін. К.: Наукова думка, 1973. 746 с.

3. Теорія держави та права: навч. посіб. / [Є.В. Білозьоров, В.П. Власенко, О.Б. Горова, А.М. Завальний, Н.В. Заяць та ін.]; за заг. ред. С.Д. Гусарєва, О.Д. Тихомирова. К.: НАВС, Освіта України, 2017. 320 с.

4. Сливич I. I. Юридичні факти в кримінальному процесі України: автореф. дис. ... канд. юрид. наук: 12.00.09. Одеса. 2007. 21 с.

5. Кайло І. Ю. Допустимість доказів у кримінальному процесі України: дис. канд. юрид. наук: 12.00.09. Харків, 2016. 2018 с.

6. Кримінальний процесуальний кодекс України від 13.04.2012 № 4651-VI.

7. Брагин Е.А. Процессуальный порядок и правовые последствия признания доказательств недопустимыми в российском уголовном процессе: автореф. дисс. ... канд. юрид. наук: 12.00.09. Челябинск, 2003. 28 с.

8. Басай Н. М. Визнання доказів недопустимими в кримінальному процесі України: автореф. дис. ... канд. юрид. наук: 12.00.09. Одеса. 2012. 22 c.

9. Кравченко С., Бабанлі Р. Кримінальне судочинство: що говорить судова статистика. Судебно-юридическая газета. 2 квітня 2020 p. URL: https://bit.ly/2xHomJo.

10. Яковлєва С. Окремі питання застосування кримінального процесуального законодавства під час розгляду кримінальних проваджень у суді. Оцінка доказів. Вебінар. URL: https://supreme.court.gov.ua/supreme/ pres-centr/news/1015664/.

11. Ухвала слідчого судді Первомайського міськрайонного суду Харківської області від 09.04.2020р. (справа № 632/2040/19). Єдиний державний реєстр судових рішень. URL: https://reyestr.court.gov.ua/ Review/88738283.

12. Ухвала слідчого судді Коростенського міськрайонного суду Житомирської області від 07.02.2019 р. (справа № 279/4283/18). Єдиний державний реєстр судових рішень. URL: https://reyestr.court.gov.ua/ Review/79725265.

14. Ухвала слідчого судді Подільського районного суду м. Києва від 11.03.2020 р. (справа № 758/1988/20). Єдиний державний реєстр судових рішень. URL: https://reyestr.court.gov.ua/Review/89224660. 


\section{Smyrnov}

\section{LEGAL CONSEQUENCES OF RECOGNITION OF EVIDENCE INADMISSIBLE: PROBLEM STATEMENT}

The purpose of the article is to define the concept of «legal consequences of declaring evidence inadmissible», to formulate their system and features of application. The article considers the problematic aspects of determining the inadmissibility of evidence. It is proved that the recognition of evidence inadmissible is a legal fact and arguments are presented to confirm this. It is established that the concept of legal consequences of recognizing evidence inadmissible is not fully covered in legal doctrine, and procedural scholars express different views on the category of the concept under study. The legislator in the provisions of the CPC of Ukraine also does not explicitly determine the legal consequences of declaring evidence inadmissible. The author supports the scientific position that in any case the exclusion of inadmissible evidence establishes certain legal consequences for the evidence base, subjects of criminal proceedings, determines the directions and limits of prosecution, criminal prosecution, application of coercive measures, affects the procedural status of the suspect, accused, as well as sentencing and decisionmaking on appeal and cassation. Based on the study of doctrinal and legislative provisions, it is determined that the system of legal consequences of declaring evidence inadmissible consists of the main and additional consequences. The main ones are: 1) the loss of legal force, the impossibility of taking it into account when making procedural decisions and when proving the circumstances that are part of the subject of proof; 2) the preliminary nature of the court's decision to declare the evidence inadmissible; 3) deletion of the reference to such evidence in the motivating part of the sentence of the court of first instance; 4) the need to take measures to verify the legality of the actions of the prosecution during the pre-trial investigation. Additional consequences are the acquittal, revocation or amendment of the sentence by the appellate court on the basis of inconsistency of the court's conclusions set out in the court decision, the facts of the criminal proceedings, as well as the closure of the proceedings.

Keywords: proof, admissibility, inadmissibility of evidence, legal fact, legal consequences. 